change or change in school performance as complaints that, either alone or in association with headaches, should make the doctor include cerebral neoplasm in his differential diagnosis. Subacute sclerosing panencephalitis may present in the same way, especially in the older child.

Compared with less than 10 years ago, when invasive diagnostic methods such as pneumoencephalography and angiography were necessary for investigating the child suspected of having a brain tumour, we are indeed fortunate in having a painless, rapid, and safe method of investigating children with ominous-sounding headaches and other symptoms and signs of recent onset. ${ }^{7}$ Nevertheless, we should use computed tomography scanning wisely and selectively. Honig and Charney, with their careful analysis of the clinical criteria for diagnosis, have helped us to do this.

Professor of Paediatrics,

N V O’DONOHOE

University of Dublin,

Trinity College,

Dublin 2

${ }^{1}$ Brown JK. Migraine and migraine equivalents in children. Dev Med Child Neurol 1977;19:683-92.

${ }^{2}$ Honig PJ, Charney EB. Children with brain tumour headaches. Distinguishing features. Am $\mathcal{F}$ Dis Child 1982;136:121-5.

${ }^{3}$ Chutorian AM, Schwartz JF, Evans RA, et al. Optic gliomas in children Neurology 1964;14:83-95.

4 Sheridan MD. Vision screening of very young or handicapped children. Br Med f 1960;ii:453-6.

${ }^{5}$ Banna M, Hoare RD, Stanley $\mathrm{P}$, et al. Craniopharyngioma in children. $\mathcal{F}$ Pediatr $1973 ; 83: 781-5$.

- Barlow CF. Headaches and brain tumours. Am $\mathcal{f}$ Dis Child 1982;136: 99-100.

7 Day RE, Thomson JL, Schutt WH. Computerised axial tomography and acute neurological problems of childhood. Arch Dis Child 1978;53:2-11.

\section{One hundred and fifty years of service}

"God help you all. What will become of you ?" John Abernethy's gloomy observation, made rather more than 150 years ago, ${ }^{1}$ was addressed to a lecture theatre full of newly enrolled Barts medical students. Doubtless some surgeons today would voice similar sentiments, prompted by the uncertainty of doctors' career prospects and reports of unemployed doctors. But even today's pessimists would acknowledge that things are not as bad as those reported by Sir James Paget, who, analysing the subsequent careers of 1000 of his own students from 1839 to 1859 , found that 280 had "failed entirely," given up medicine, or died, and that another 120 had achieved "very little success." That today's prospects for a rewarding professional career in medicine are rather better has been due in no small part to the work of the British Medical Association, launched just 150 years ago, and serving the profession ever since.

Sir Charles Hastings, who founded the Provincial Medical and Surgical Association in Worcester in the year of the Reform Bill, proposed that the new organisation, which in 1855 became the British Medical Association, should be "both friendly and scientific." But one of the chief motives of Hastings and his founding colleagues was "to assert their independence of the capital."2 While the Association has remained both friendly and scientific, the attractions of the capital proved too powerful to resist, and headquarters soon came to and have since remained in London, where the
Annual Representative Meeting is being held this year, with a royal president, HRH, The Prince of Wales, to honour its 150th celebrations.

During the past decade two events have profoundly in- $\frac{3}{1}$ fluenced the BMA's future work. Firstly, the BMA has $Q$ become a union and, secondly, it has redirected its efforts to $\overparen{C}$ advising and helping doctors where they work and live rather $\overline{\bar{F}}$ than from the remoteness of the London headquarters. ID Hastings would have certainly approved of shedding some of $\$$ the London influence, but he was a practical visionary and $\stackrel{0}{\varrho}$ he would have almost as certainly recognised the need for the Association to accept formal union status in order to further $\overrightarrow{\vec{D}}$ its members' interests. After all, the Provincial Medical and $\bar{O}$ Surgical Association's most urgent task in 1832 was to im- o prove doctors' economic and professional prospects as an essential part of improving standards of medicine.

This was achieved through the setting up of the General is Medical Council by the Medical Act of 1858, an event that $\overrightarrow{0}$ represented the Association's first significant parliamentary success, a success repeated over a century later when the $\vec{\omega}$ BMA campaigned for and achieved major reforms in the $\bar{\partial}$ GMC. $^{3}$ The means may have changed, but the aims have not altered. The Medical Act of 1858 achieved the aim through ${ }_{\infty}^{\infty}$ raising educational standards and regulating the conduct of of practice. Though the approach to improving remuneration $\mathscr{\omega}_{\vec{\omega}}$ and terms and conditions of service today is more direct, it is by no means exclusively based on self-interest. The BMA has a fine record of public health achievement behind it and can $\omega$ present its claims in terms of the ensuing improvement in health care. This serves to distinguish us from the industrial unions, whose sole purpose would too often appear to be to $\vec{\bullet}$ better their own members' terms and conditions of service.

Dr Alfred Cox, a distinguished past secretary of the BMA, addressing the North of England Branch just 50 years ago, ${ }_{4}^{4}$ had this to say on the Association and unionism: "We are often told by people in the press and in Parliament,
some of whom intend to pay us a compliment, and others to
be disagreeable, that the Association is 'the strongest trade
union in the country.' If that means, as it is often intended
to mean, that we are a vigorous and well organised body,
which does its best to protect the lawful interest of its mem-
bers, then we accept the compliment, but when it is meant
to imply that we adopt illegitimate or unsocial means for
imposing our will arbitrarily on the community we 'deny
the allegation and spurn the allegator.'... [The Association]
could not employ the methods of the industrial trade unions
for many reasons, but mainly because it consists of men and
women dedicated in a peculiar sense to the service of the
community. So long as this is the living tradition of our
profession, so long shall we enjoy that respect and trust
which is extended to us as it is to no other body of men and
women."

Half a century later that comment is still valid and should persuade those members of the BMA who believe that the Association should concentrate on members' terms and + conditions of service to the exclusion of anything else to think $\frac{0}{0}$ again. A claim for improvements based on the consequential benefit to the Health Service is likely to carry far more weight $\frac{\vec{D}}{\mathrm{D}}$ than a bald request for more money, particularly when it is submitted by an Association whose concern for the reduction of mortality and morbidity can be shown on occasion to transcend the interests even of its own members. Seat-belt legislation, which has been so strongly and effectively pressed by the BMA, has its critics among our members, but the 
criticisms are based on issues of conscience and free will and not on the possible redundancies of doctors working in accident and emergency departments.

But there is a limit to which altruism can be expected of doctors in a materialistic age, and the Association's appreciation of this point has been shown by the rapid expansion of its regional services ( $p$ 71). The full-time industrial relations officers now appointed in nearly every region, whose main purpose is to help members with employment problems, whether as employees or employers, have been a success. There is no doubt in my mind that, because doctors realise that the BMA has now taken active and effective steps to help them individually, more have joined the Association, to produce a record increase in membership over the last three years. The net increase of over 3500 members, as compared with this time last year, speaks for itself. Even so, when expressed as a proportion of practising doctors, the BMA's membership is still unacceptably low and the danger of complacency is great.

Though doctors have their troubles they should keep them in perspective. Despite the fact that unemployment among doctors is edging up, with career prospects becoming less certain, they still work in a relatively secure vocation, surrounded by occupations which have been experiencing the severest redundancies in living memory. Doctors are, however, an expensive national resource and the country cannot afford to misemploy them, but despite the efforts over the years to find a universally satisfactory solution to medical manpowerand the BMA has played a big part in these efforts-the answer still eludes the profession. The Goodenough Interdepartmental Committee on medical schools got it wrong in the $1940 \mathrm{~s},{ }^{5}$ the Willink Committee's efforts were even worse in the $1950 \mathrm{~s},{ }^{6}$ and the Royal Commission on Medical Education failed to find the right answer in the $1960 \mathrm{~s}^{7}$ The associated problems of the hospital staffing career structure have been examined by committees too numerous to mention, and their repeated failures explain the sceptical response of many doctors to the Short Committee's recent proposals and the Government's support for them. Throughout all these developments the profession has needed a strong body to represent its views and to prevent the Government from taking premature action to introduce changes which would be to the disadvantage of doctors and patients. The BMA supplies this need, which is never greater than when the profession is itself divided on the issue-unhappily the case on manpower.

Since its founding the BMA has contributed extensively to improving public health and shaping health and social policies, a record that the public recognises. Even so, in this media-dominated age in which pressure groups flourish medicine and its practitioners are being subjected to an unprecedented amount of public scrutiny, sometimes justified, often not. Issues of extracorporeal (in-vitro) fertilisation, resuscitation of babies born with life-threatening abnormalities, data protection, and the treatment of the mentally ill have all led to criticism of what we have so far regarded as acceptable medical practices, to such an extent that doctors of impeccable professional standing have been threatened with criminal prosecution, or in one notable case put on trial for murder. Again, the need for a powerful body, able to speak and act on behalf of all branches of the profession, is of paramount importance to face the well-organised pressure groups mounting unprecedented attacks on medical practices.

These pressure groups, society's changing values, reorganisations of the NHS that have strengthened its bureaucracy, and the growth of militant unionism among health workers are all challenging doctors' traditional leadership in medicine. This challenge is by no means based on a concern for patients and if successful the community will be the loser. As the BMA moves towards its second century it will see that this challenge will be met firmly and responsibly in the interests of both its members and their patients.

J D J HAVARD

Secretary,

British Medical Association

1 Vaughan P. Doctors' commons. London: Heinemann, 1959:35.

2 Vaughan P. Doctors' commons. London: Heinemann, 1959:1.

${ }^{3}$ Medical Act 1978. London: HMSO, 1978.

4 Cox A. A confession of faith. Br Med F 1932;i, suppl:94.

5 Ministry of Health. Report of interdepartmental committee on medical schools. London: HMSO, 1944. (Goodenough Report.)

6 Committee to consider the future numbers of medical practitioners and the appropriate intake of medical students. Report. London: HMSO, 1957. (Willink Report.)

${ }^{7}$ Royal Commission on Medical Education, 1965-8. Report. Cmnd 3569. London: HMSO, 1968. 